\title{
MECHANISMS OF DROUGHT RESISTANCE IN GRAIN LEGUMES I: OSMOTIC ADJUSTMENT
}

Tilahun Amede ${ }^{1}$ and Sven Schubert ${ }^{2}$

\author{
${ }^{1}$ International Centre for Tropical Agriculture (CIAT), African Highlands Initiative Code 1110 \\ PO Box 1412, Addis Ababa, Ethiopia. E-mail: T.Amede@CGIAR.ORG
}

${ }^{2}$ Justus-Liebig Universitaet, Institut fuer Pflanzenernaehrung, Giessen, Germany

\begin{abstract}
When crops are exposed to drought there is commonly an increase in solute-pool of the plant tissue. A series of experiments were conducted in 1994 and 1995 in the University of Hohenheim, Germany, to evaluate whether drought-induced solute accumulation per se will improve drought resistance, to determine the species of active osmotica involved, and to identify alternative mechanisms in grain legumes, namely Common bean (Phaseolus vulgaris) faba bean (Vicia faba), pea (Pisum sativum), and chickpea (Cicer arietinum). Drought, equivalent to soil water potential of $-0.64 \mathrm{MPa}$, decreased the leaf water potential to $-1.67,-1.83,-0.34$ and $-1.32 \mathrm{MPa}$ and resulted in dry matter yield reduction of $36.4 \%, 23.9 \%, 17.6 \%$ and $14.5 \%$ in faba bean, pea, common bean, and chickpea, respectively. Higher yield of chickpea and common bean under drought was augumented by turgor maintenance. The highest degree of turgor $(1.0 \mathrm{MPa})$ was in common bean, though it had the lowest solute accumulation. Thus, a decrease in osmotic potential was not the only strategy of turgor maintenance in legumes. Increase in solute pool in all was due to concentration effect as a result of water loss and growth inhibition, except in chickpea. The major osmotica in chickpea were of organic origin, namely sugars and sugar alcohols contributing more than 50\%, and amino compounds $20 \%$ of the osmotic pool. Calcium was the only inorganic osmoticum contributing $19 \%$ of the pool. Concentration of solutes in the cell-sap did not necessarily indicate the level of contribution to the osmotic pool, as the most abundant ions (e.g., potassium) did not contribute to osmotic adjustment under drought. It was concluded that it is vital to differentiate solutes accumulated as a concentration effect from active osmotica using cell water volume of control plants before considering solute concentration as a selection criterion for breeding drought resistant varieties/crops.
\end{abstract}

Key words/phrases: Active osmotica, concentration effect, drought, grain legumes

\section{INTRODUCTION}

Grain legumes are the principal components of farming systems of Sub-saharan Africa. Legumes serve as sole protein sources for humans and animals, and also as break crops in crop rotation to abridge decline in soil fertility. However, productivity of legumes grown in sub-saharan Africa is limited mainly by drought. Despite the alarming demand for drought-resistant cultivars of grain legume, breeders are slow in achieving this goal due to the challenge in identifying traits that reflect true drought resistance.

When crops are exposed to drought, they may alter cell solute concentration by allocating resources so that the osmotic potential of the cell is reduced, and turgor is maintained (osmotic adjustment). Osmotic adjustment, through accumulation of effective osmotica, is an important mechanism of drought resistance in legumes (Ford, 1984; Tilahun Amede, 1998). However, accumulation of solutes in the plant cell per se does not guarantee osmotic adjustment. Besides osmotic adjustment, solute deposition in plant cells under drought stress could have four principal causes (Tilahun Amede, 1998). Firstly, plants may lose substantial amounts of water that may lead to a reduction in the expansion rate of the tissue (reduced cell volume), and thereby to an accumulation of solutes in the cell. Secondly, some primary metabolites (proteins, carbohydrates or lipids) may be degraded at higher stress intensities, and the by-products could accumulate as secondary metabolites in the cell. Thirdly, decrease in cell elongation (growth) may cause slowing down of assimilate biosynthesis, but effective import of assimilates to the sink cells could be high enough to increase the concentration of solutes and ultimately cause a reduction in the osmotic potential of the cell (Kramer and Boyer, 1995). Fourthly, under moderate levels of stress, roots may still actively absorb inorganic ions (potassium, calcium, sodium, magnesium, chloride, and others) from the soil. Nutrients may not be utilised by the 
plant owing to drought-induced growth inhibition but instead, translocated ions may accumulate in the cells and induce substantial reduction in osmotic potential (Munns, 1988). Therefore, there is a need to differentiate active osmotica from solutes accumulated as a response to water loss and growth inhibition before considering them as selection criteria for drought resistance.

Genotypes with higher solute accumulation produced higher grain yield than those with lower solute accumulation under drought conditions in wheat (Morgan 1983; 1992) and in sorghum (Premachandra et al., 1995). In this case, solute concentration in the plant tissue could be used as a trait to select potentially drought resistant inbred lines. In other cases, proline in cassava (Sundaresan and Sudhakaran, 1995) and sugar in cotton (Timpa et al., 1986) accumulated more in drought-sensitive genotypes while these compounds decreased or remained unchanged in drought-tolerant genotypes. Moreover, droughtsensitive faba bean inbred lines accumulated more solutes than drought tolerant ones when exposed to drought (Tilahun Amede et al., 1999). These contradictory results have originated from methodological problems to differentiate active osmotica from solutes accumulated as a result of concentration effects (Munns, 1988; Tilahun Amede et al., 1999).

The objectives of this study were (i) to determine the effect of water stress on growth and dry matter synthesis of faba bean, pea, common bean and chickpea plants, (ii) to investigate possible strategic differences in drought resistance in the tested legumes in terms of water use, water potential, osmotic potential and turgor, (iii) to differentiate between drought-induced accumulation of true osmotica from solutes accumulated due to a concentration effect, and (iv) to identify in which, if any, of the tested legumes osmotic adjustment occurs under drought, and which species of osmotica are involved.

\section{MATERIALS AND METHODS}

\section{Growth conditions and management}

Faba bean (Vicia faba cv. Alfred), pea (Pisum sativum cv. Belman), common bean (Phaseolus vulgaris cv. Brilliant), and chickpea (Cicer arietinum cv. Gab-3) were grown in greenhouse in 1994 and 1995. A loess soil was collected from the experimental field of the University of Hohenheim, which has the following characteristics (Feuerle, 1996):

$$
\begin{array}{ll}
\mathrm{N}_{\min }: & 25 \mathrm{~kg} \mathrm{~N} \mathrm{ha}^{-1} \\
\mathrm{P}(\mathrm{CAL}) & 157 \mathrm{mg} \mathrm{P} \mathrm{kg} \mathrm{soil}^{-1}
\end{array}
$$

$\begin{array}{ll}\mathrm{K}(\mathrm{CAL}) & 323.7 \mathrm{mg} \mathrm{K} \mathrm{kg} \mathrm{soil}{ }^{-1} \\ \mathrm{Mg}\left(\mathrm{CaCl}_{2}\right) & 130 \mathrm{mg} \mathrm{Mg} \mathrm{kg} \mathrm{soil}^{-1} \\ \mathrm{pH}\left(\mathrm{CaCl}_{2}\right) & 6.2\end{array}$

The soil was mixed with $37 \%$ sand, and $143 \mathrm{mg}$ $\mathrm{N}, 62.41 \mathrm{mg} \mathrm{P}, 166 \mathrm{mg} \mathrm{K}, 14.5 \mathrm{mg} \mathrm{Mg}$ and $71 \mathrm{mg}$ $\mathrm{kg}^{-1} \mathrm{~S}$ per $\mathrm{kg}$ soil were added as a complete fertiliser 'Blaukorn' before planting. In addition, some nitrogen may have been supplemented by natural nitrogen fixation. Seeds were sown directly into pots on May 24 $4^{\text {th }}, 1994$ and April 3 $3^{\text {rd }}, 1995$ into Mitscherlich pots filled with $7 \mathrm{~kg}$ of soil and sand mixture (5:3). Each treatment had four replications. The transpiration rate of each species was determined gravimetrically from a series of trials in pots with or without plants, where four plants of faba bean and chickpea were found to transpire about the same amount of water as five plants of the other species. Adjacent plant-free pots were used to estimate evaporation, assuming that all tested species had similar ground cover. Water use efficiency was calculated as the ratio between biomass produced and the amount of water transpired.

One week after emergence, seedlings were thinned to four plants of faba bean and chickpea, and five plants of common bean and pea per pot. Plants were left to grow at 70 to $80 \%$ soil water capacity (SWC) until the beginning of the water stress treatments. When plants were 50 days old, a period of eight or fifteen days of water stress was applied by withholding water. Water stress was imposed very slowly but continually for 8 and 15 days by adjusting the weight of the pots to the desired SWC. Treatments were harvested in a systematic order between $11.00 \mathrm{~h}$ and $14.00 \mathrm{~h}$. Since yield differences among species in response to drought ceased at 15 days stress (data not shown), mainly 8 day stress treatments were considered to identify mechanisms of drought resistance in this work.

Because of similar responses of plants to growing conditions in 1994 and 1995, only results from 1995 are presented. In the growth period, the average daily mean temperature was $19^{\circ} \mathrm{C} \pm 3.2$ and the average daily mean relative humidity was $45 \% \pm 11.7$.

\section{Components of water potential}

At harvesting, fresh weight was determined and midday leaf water potential $\left(\psi_{\mathrm{w}}\right)$ of fully developed youngest leaves was measured by the pressure probe technique (Scholander et al., 1965). About $13 \mathrm{~g}$ of young, fully developed, freshly harvested leaves were frozen in liquid nitrogen and kept in a deep freezer $\left(-20^{\circ} \mathrm{C}\right)$ until press sap extraction. The press sap was centrifuged at 4000 
rpm for 5 minutes, diluted with double distilled water, divided into a number of portions and kept at $-20^{\circ} \mathrm{C}$ again until chemical analysis. The whole sample preparation was conducted under 0 to $4^{\circ} \mathrm{C}$. All chemical analyses and determinations of osmotic potential were conducted using the presssap. Solute concentration (mosm) of the pressed sap (osmolarity) was measured using a freezing point osmometer (Type Digital, Knauer, KG). Osmotic potential (MPa) was derived from solute concentration according to Van't Hoffs' equation as follows:

$$
\begin{gathered}
\psi_{\mathrm{S}}(\mathrm{MPa})=\text { mOsmol } \times \text { gas constant }(0.831) \times \\
10^{-5} \times \text { Temperature }\left({ }^{\circ} \mathrm{K}\right)
\end{gathered}
$$

Turgor potential $\left(\psi_{t}\right)$ was calculated as follows:

$$
\psi_{\mathrm{t}}=\psi_{\mathrm{s}}-\psi_{\mathrm{w}}
$$

where $\psi_{\mathrm{S}}$ and $\psi_{\mathrm{w}}$ are the osmotic potential and water potential of the leaf, respectively.

Soil water contents were measured gravimetrically and converted to soil water potentials based upon the soil water retention curve. Soil water retention was estimated according to Vereecken et al. (1989) by a multiple regression model using a set of soil properties as predictor variables.

After collecting samples of young leaves for the determination of water and osmotic potential, the rest of the shoot was harvested and fresh weight was immediately determined. Samples for osmotic potential and water potential were also weighed and considered both in fresh and dry weight of the respective treatments. Dry matter was estimated after oven drying $\left(105^{\circ} \mathrm{C}\right)$ to constant weight.

\section{Analytical methods}

\section{Determination of solutes}

Analysis of sugars (glucose, fructose and sucrose) and sorbitol was conducted using enzymatic test kits (Boehringer, Mannheim). Inositols were measured by spectrophotometry using the procedure of Bose et al. (1963).

Amino acids and proline were determined by spectrophotometry using ninhydrin reagent according to the methods of Rosen (1957) and Bates (1973), respectively. Quaternary ammonium compounds were analysed by the precipitation of periodide complexes (Grieve and Grattan, 1983). Ureides were measured photometrically using potassium ferricyanide as the colour indicator (Peoples et al., 1989).
Potassium and calcium were determined by flame photometery (Eppendorf Elex 6361) after press sap had been diluted with $3 \% \mathrm{HNO}_{3}$ (using double-distilled water). Magnesium was determined using an atomic absorption spectrometer (Unicam 939).

Phosphate, nitrate and chloride were measured by ion chromatography (dilution 1:120). The eluents were mixtures of $1.7 \mathrm{mM} \mathrm{NaHCO} 3$ and 1.8 $\mathrm{mM} \mathrm{Na} \mathrm{CO}_{3}$ and ions were measured using a conductivity detector (ion chromatography 2000 i/SP Dionex).

\section{Quantification of effective solutes (osmotica)}

Effective osmotica of drought stressed plants were differentiated from solutes due to a concentration effect (water loss and growth inhibition) as follows (Tilahun Amede et al., 1999).

The effective solutes ( $ठ)$ were determined by correcting the solute concentration of stressed plants $\left(\partial_{\mathrm{S}}\right)$ with a correction factor $(\mathbf{C F})$ :

$$
\text { ð }=ð_{\mathrm{s}} * \mathrm{CF} \quad \text { with } \quad C F=\frac{F W S}{F W C}
$$

where FWS and FWC are fresh weights of stressed and control plants, respectively.

Since more than $80 \%$ of the fresh weight is water, CF will eliminate the concentration of solutes that accumulate as a result of passive dehydration and/or growth inhibition. Osmotic adjustment (OA) was calculated as follows:

$$
\mathrm{OA}=\left(\partial_{\mathrm{S}} * \mathbf{C F}\right)-\partial_{\mathrm{C}}
$$

with $\partial_{\mathrm{C}}$ denoting the solute concentration of control plants.

The contribution of an individual osmoticum (sugars, amino acids, $\mathrm{K}^{+}$, etc.) to the osmotic pool was calculated as follows:

$$
C F=\frac{\beta_{s}-\beta_{c}}{ð_{\text {So }}-ð_{\mathrm{Co}}} \times 100
$$

where $\beta_{\mathrm{S}}$ and $\beta_{\mathrm{C}}$ are concentrations of effective solutes of various ions as determined separately, and $\partial_{\mathrm{So}}$ and $\partial_{\mathrm{Co}}$ are total osmolarities of stress and control plants as determined by the use of an osmometer, respectively.

Statistical differences among treatments were determined using analysis of variance and t-test. 


\section{RESULTS}

\section{Biomass production and water use}

There was a linear increase in water use with increasing growth, regardless of species. However, at a given growth stage water demand was dictated mainly by daily temperature (data not shown). On cooler days, water use was lower than the average daily water demand, even during the later growth stages with higher expansion growth.

Visual observations of the species indicated that after the second day of stress, leaves of faba bean plants started to wilt, and partly changed leaf orientation towards the sunlight. Five days after the onset of stress, common bean plants exhibited leaf rolling and changed leaf orientation during the hottest part of the day. The response of chickpea and pea to drought was different from the other two legumes in that after 10 days of stress a considerable abscission of older leaves was observed. Relative water content (RWC) of faba bean and common bean under well-watered conditions was higher than $85 \%$, while RWC in chickpea and pea was lower than $80 \%$. These differences in tissue water content between species were significant $(\mathrm{p}<0.05)$, and they are presumably genetically controlled.

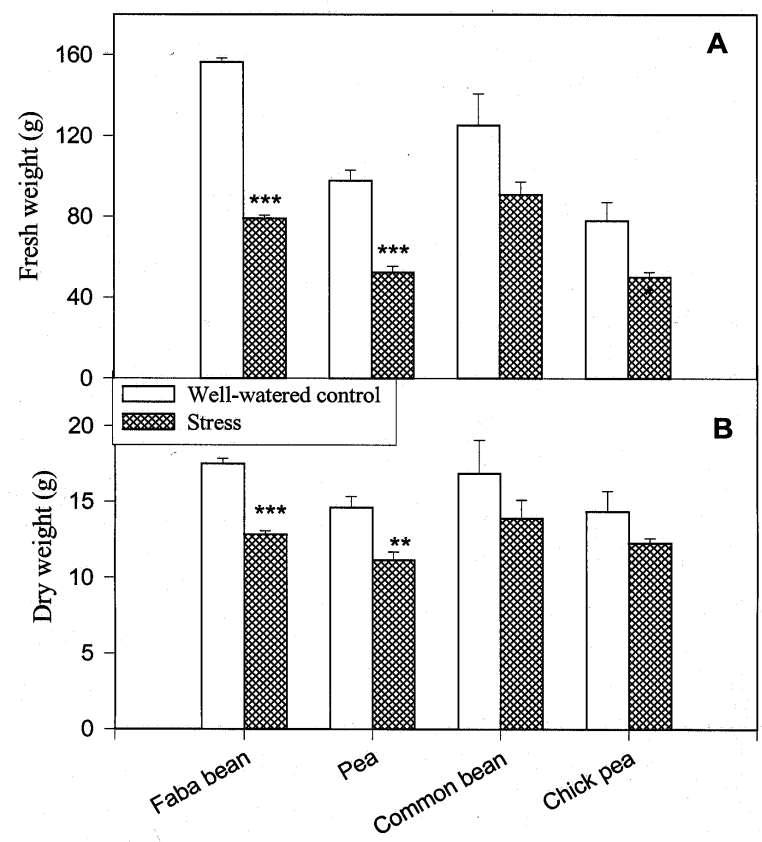

Fig. 1. Effect of 8 days drought on fresh weight (A) and dry weight (B) of grain legumes. ${ }^{*}, * * * * *$ show differences between control and stress (effective solutes) at $\mathbf{P}<0.05,0.01$ and 0.001 level of significance, respectively. Bars indicate $\pm \mathrm{SE}$.
Drought reduced the biomass of all four species. However, there was a significant difference between species in response to drought (Fig. 1). Biomass reduction due to drought was higher in faba bean and pea $(p<0.001)$, than in common bean and chickpea (Fig. 1). In common bean and chickpea, dry matter synthesis under drought was not significantly different from well-watered control plants.

Transpiration coefficients of the tested faba bean, pea, common bean and chickpea genotypes were 262, 263, 201 and $346 \mathrm{ml}$ water $\mathrm{g}^{-1} \mathrm{DM}$, respectively. There was no significant difference in water use efficiency between faba bean and pea. However, chickpea had a significantly lower water use efficiency while common bean had higher water use efficiency than the other species, in spite of the fact that both produced relatively more dry matter (\% control) under stress conditions.

\section{Components of water potential}

There was a strong reduction in plant water potential $\left(\psi_{\mathrm{w}}\right)$ in all tested species, except common bean. Drought caused a greater reduction in $\psi_{\mathrm{w}}$ of faba bean (by -1.01 MPa) than of common bean (by only $-0.08 \mathrm{MPa}$ ) (Fig. 2). The osmotic potential ( $\left.\psi_{\mathrm{s}}\right)$ of the three legumes other than common bean was significantly reduced $(p<0.001)$ under drought conditions (Fig. 2). In chickpea, both $\psi_{\mathrm{w}}$ and $\psi_{\mathrm{s}}$ were reduced, and the reduction in $\psi_{\mathrm{s}}$ was sufficient to maintain turgor. The highest degree of turgor maintenance, about $1 \mathrm{MPa}$, was achieved by common bean, although common bean had the lowest solute accumulation (Table 1). Regardless of the significant reduction in $\psi_{\mathrm{s}}$ of faba bean and pea plants, both species lost turgor under drought. There was no significant reduction in $\psi_{\mathrm{S}}$ and presumably no osmotic adjustment in common bean (Table 1). Reduction in $\psi_{\mathrm{s}}$ in faba bean, pea and common bean was not due to osmotic adjustment but rather due to a concentration effect (Table 1), which is caused by water loss and/or growth inhibition. The concentration effect, in terms of growth inhibition and water loss, was 49 , 47,36 and $27 \%$ for faba bean, pea, chickpea, and common bean, respectively. After the level of solute concentration of drought-stressed legumes had been corrected for water loss and growth inhibition, only chickpea, but none of the other species, showed osmotic adjustment (Table 1). 
Table 1. The concentration of solutes in young leaves of various legumes under well-watered (control) and stress conditions.

\begin{tabular}{lccll}
\hline & $\begin{array}{l}\text { Faba } \\
\text { bean }\end{array}$ & Pea & $\begin{array}{l}\text { Common } \\
\text { bean }\end{array}$ & $\begin{array}{l}\text { Chick } \\
\text { pea }\end{array}$ \\
\hline $\begin{array}{l}\text { A:solutes (mosm) } \\
\text { Control }\end{array}$ & 402.7 & 475.5 & 433.5 & 410.3 \\
$\begin{array}{l}\text { Stress } \\
\text { Stress, ə }\end{array}$ & 668.2 & 753.7 & 522.0 & 755.3 \\
& $340.8 *$ & $406.3 *$ & 378.9 & 484.1 * \\
B. solutes (mM) & & & & \\
$\begin{array}{l}\text { Control } \\
\text { Stress }\end{array}$ & 328.5 & 236.3 & 357.8 & 315.4 \\
Stress, ə & 531.8 & 444.4 & 533.1 & 620.1 \\
\hline
\end{tabular}

A) Solute concentration (mosm) of the press-sap measured by means of an osmometer;

B) The sum of various organic and inorganic solutes after solutes were determined photomerically.

*Indicates statistical differences $(p<0.05)$ between control and stress $\partial$ (effective solutes after correction for concentration effect).

\section{Contribution of various solutes to osmotic potential and osmotic adjustment}

\section{Sugars and sugar alcohols}

The concentrations of water-soluble sugars and drought-induced changes in sugar concentrations varied between species (Table 2). Generally, drought reduced the sugar reserve of common bean, pea, and faba bean while it increased the sugar reserve of chickpea. Accordingly, fructose concentrations significantly increased in chickpea but decreased in pea and faba bean. As with fructose, the level of glucose was also increased by drought in chickpea but was decreased in faba bean and common bean. Drought decreased the contribution of hexoses to the osmolarity (osmotic potential) of common bean from about $15 \%$ under well-watered conditions to about $6.5 \%$ under drought (Table 2). On the other hand, drought did not affect the contribution of hexoses to the osmolarity (16\%) in chickpea, although droughtinduced change in photosynthesis rate is to be expected. In contrast to hexoses, sucrose concentration was extremely low in common bean plants, and drought did not alter this concentration. In chickpea, drought also increased the concentration of sucrose significantly (Table 2 ). The contribution of sucrose to the osmolarity of the press-sap in common bean was about $0.6 \%$, but this was tenfold in chickpea (Table 2). In general, fructose and sucrose accounted for about 25\% of the total effective osmotic pool in chickpea, excluding sugars accumulated due to concentration effect. More than $55 \%$ of the contribution of water soluble sugars to osmotic adjustment was accounted for by sucrose.

Sorbitol concentration was generally low, though it increased with stress. The case was different in faba bean where drought increased the absolute sorbitol level from $30 \mathrm{mM}$ to $53 \mathrm{mM}$ (Table 2a), which was about $12 \%$ of the total osmolarity. Drought-induced inositol accumulation was significantly higher in chickpea and common bean (Table $2 \mathrm{~b}$ ) and exceeded the concentration effect. Inositiols constituted $25 \%$ of the osmotic adjustment. Sugars and sugar alcohols together contributed to about $50 \%$ of the total osmotic adjustment in chickpea plants.

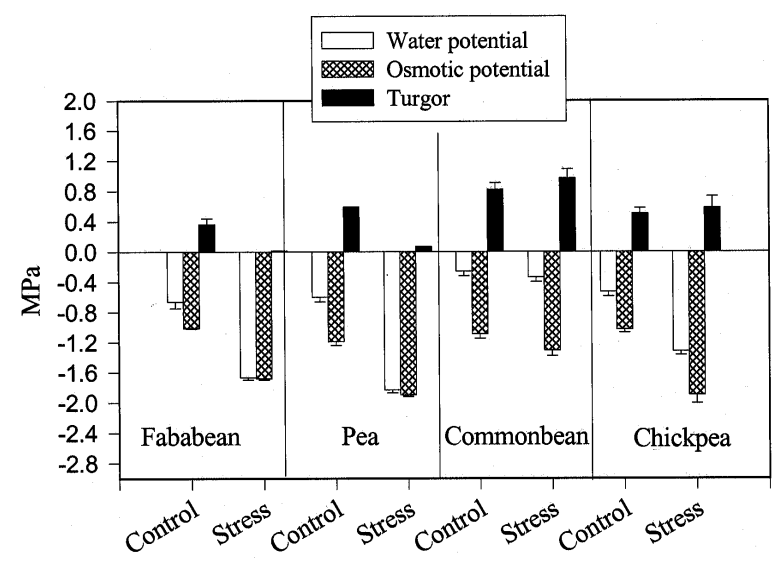

Fig. 2. Effect of 8 days water stress on water potential, osmotic potential and turgor of grain legumes. The positive values indicate turgor while the negative values show osmotic and water potentials. Bars indicate \pm SE. $n=4$.

\section{Amino compounds}

Drought caused a considerable accumulation of amino acids in all tested species, and the accumulation in all cases was more than could be explained by a concentration effect (Table 2). The concentration of amino acids and its contribution to the solute pool increased with decreasing water potential both in total or effective amino acid concentrations. The contribution of amino acids to osmotic adjustment in chickpea was $18.6 \%$. Proline is the major amino acid that accumulates in the plant tissue under stress conditions (Singh et al., 1973). There was a significant accumulation of proline in all tested species $(\mathrm{P}<0.01)$. The accumulation, in all tested species except for common bean, was much higher than could be explained by a concentration effect (Table 2). Except common bean, about 20 to $25 \%$ of the total amino acid accumulation of the stressed plants was contributed by proline. The relationship between proline concentration and level of water potential was exponential (Fig. 3), which suggests a significant decrease in water potential for a unit decrease in proline concentration. However, the considerable drought-induced increase in proline concentration was obtained mainly in the relatively drought-sensitive crops (faba bean and pea) (Table 2a). 
Table 2a. Drought stress effects on the accumulation of solutes (mM) in young leaves of Faba bean and Pea. The absolute and effective values indicated the measured and the corrected values of stressed plants, respectively. ${ }^{*}, * * * * *$ indicate significant levels at $\mathrm{p}<0.05,0.01$ and $0.001 \%$, respectively.

\begin{tabular}{|c|c|c|c|c|c|c|}
\hline \multirow{3}{*}{ Solutes } & \multicolumn{3}{|c|}{ Faba beans $(\mathrm{mM})$} & \multicolumn{3}{|c|}{ Pea $(\mathrm{mM})$} \\
\hline & \multirow[t]{2}{*}{ Control (SE) } & \multicolumn{2}{|c|}{ Stress (SE) } & \multirow[t]{2}{*}{ Control (SE) } & \multicolumn{2}{|c|}{ Stress (SE) } \\
\hline & & Absolute & Effective & & Absolute & Effective \\
\hline Amino acids & $24.71(1.14)$ & $58.64(1.48)$ & $29.90(0.75)$ & $42.26(2.80)$ & $95.51(9.40)$ & $51.09(0.27)^{* *}$ \\
\hline Proline & $2.95(0.20)$ & $18.64(3.2)$ & $9.50(1.36)^{*}$ & $3.1(0.24)$ & $25.85(2.70)$ & $13.83(1.44)^{* *}$ \\
\hline QAC & $8.70(0.88)$ & $8.73(0.87)$ & $4.46(0.44)$ & $7.84(0.79)$ & $12.84(1.74)$ & $6.87(0.93)^{*}$ \\
\hline Ğlucose & $20.37(0.86)$ & 16.36 (1.44) & $8.34(0.74)^{*}$ & $15.70(0.53)$ & 51.95 (1.02) & $27.79(0.54)$ \\
\hline Fructose & $15.68(0.68)$ & $11.46(0.94)$ & $5.84(0.48)^{*}$ & $9.47(0.899$ & $14.48(1.28)$ & $7.74(0.68)$ \\
\hline Sucrose & $14.86(0.83)$ & $17.49(2.20)$ & $8.92(1.12)^{*}$ & $21.24(1.40)$ & $29.66(2.65)$ & $15.86(1.42)$ \\
\hline Sorbitol & 30.20 (3.72) & $52.62(1.58)$ & $26.00(1.00)$ & $6.21(0.24)$ & $15.94(0.71)$ & $8.52(0.39)$ \\
\hline Inositol & $20.11(6,45)$ & $32.76(2,99)$ & $16.71(1.52)$ & $2.25(1.25)$ & $6.42(1.14)$ & $3.69(0.61)$ \\
\hline Ureids & n.d. & n.d. & n.d. & n.d & n.d & n.d \\
\hline $\mathrm{K}^{+}$ & 134.24 (2.95) & $216.55(4.56)$ & $\begin{array}{l}110.44 \\
(2.32)^{*}\end{array}$ & $87.95(2.55)$ & $119.45(5.75)$ & 63.89 (3.07) \\
\hline $\mathrm{Ca}^{+2}$ & $20.96(0.77)$ & 56.97 (3.46) & $\begin{array}{r}29.06 \\
(1.76)^{*}\end{array}$ & $23.79(0.70)$ & $61.60(9.31)$ & $32.95(4.98)^{*}$ \\
\hline $\mathrm{Mg}^{+}$ & $10.88(0.76)$ & $23.08(0.44)$ & $11.77(0.23)$ & n.d & n.d & n.d \\
\hline $\mathrm{PO}^{-3}$ & $10.58(0.79)$ & $13.43(0.85)$ & $6.85(0.43)$ & $10.79(0.85)$ & $15.46(1.38)$ & $8.27(0.74)$ \\
\hline No3- & $2.09(0.27)$ & $3.58(0.24)$ & $1.83(0.12)$ & $3.36(0.57)$ & $8.00(0.67)$ & $4.28(0.36)$ \\
\hline $\mathrm{Cl}^{-}$ & 15.15 (0.38) & $20.17(1.39)$ & $10.28(0.71)$ & $5.46(0.36)$ & $12.60(0.77)$ & $6.74(0.41)$ \\
\hline Total & 328.53 & 531.84 & 270.40 & 236.32 & 444.41 & 237.31 \\
\hline
\end{tabular}

Table $2 \mathrm{~b}$. Drought stress effects on the accumulation of solutes (mM) in young leaves of Common bean and chickpea. The absolute and effective values indicated the measured and the corrected values of stressed plants, respectively. ${ }^{* * *}, * * *$ indicate significant levels at $\mathrm{p}<0.05,0.01$ and $0.001 \%$, respectively.

\begin{tabular}{|c|c|c|c|c|c|c|}
\hline \multirow{3}{*}{ Solutes } & \multicolumn{3}{|c|}{ Common bean (mM) } & \multicolumn{3}{|c|}{ Chickpea (mM) } \\
\hline & \multirow[t]{2}{*}{ Control (SE) } & \multicolumn{2}{|c|}{ Stress (SE) } & \multirow[t]{2}{*}{ Control (SE) } & \multicolumn{2}{|c|}{ Stress (SE) } \\
\hline & & Absolute & Effective & & Absolute & Effective \\
\hline Amino acids & $14.70(0.63)$ & $28.61(1.94)$ & $20.77(1.41)^{*}$ & $28.65(2.99)$ & $72.41(1.35)$ & $46.34(0.86)^{* *}$ \\
\hline Proline & $0.29(0.33)$ & $2.33(0.44)$ & $1.69(0.32)$ & $2.81(0.65)$ & 14.53 (1.35) & $9.30(0.86)$ \\
\hline QAC & $8.58(0.65)$ & $15.28(1.23)$ & $11.09(0.89)^{*}$ & 7.59 (1.00) & $11.43(0.69)$ & $7.32(0.44)$ \\
\hline Glucose & $37.81(3.96)$ & $22.47(8.11)$ & $16.30(5.89)$ & $51.53(3.64)$ & $85.86(6.33)$ & $55.00(4.06)^{*}$ \\
\hline Fructose & $25.33(2.35)$ & $15.20(3.45)$ & $11.04(2.51)$ & $14.47(0.55)$ & $32.57(2.21)$ & $20.88(1.42)^{*}$ \\
\hline Sucrose & $2.10(0.83)$ & $3.53(0.24)$ & $2.57(0.71)$ & 12.46 (1.08) & 44.16 (4.69) & $28.30(3.01)^{*}$ \\
\hline Sorbitol & $4.40(0.45)$ & $6.05(0.98)$ & $3.94(0.68)$ & $4.74(0.72)$ & $12.14(0.19)$ & $7.60(0.21)$ \\
\hline Inositol & $13.50(1.52)$ & $40.88(2.56)$ & $29.70(1.86)^{*}$ & $2.84(2,80)$ & 41.51 (3.69) & $26.61(2.37)^{* *}$ \\
\hline Ureids & $1.50(0.30)$ & $5.73(0.44)$ & $4.16(0.32)^{*}$ & n.d. & n.d. & n.d. \\
\hline $\mathrm{K}^{+}$ & $\begin{array}{c}141.36 \\
(5.63)\end{array}$ & $\begin{array}{c}210.96 \\
(4.91)\end{array}$ & $153.16(3.57)$ & $129.01(7.86)$ & $188.42(8.64)$ & $120.78(5.54)$ \\
\hline $\mathrm{Ca}^{+2}$ & 53.78 (5.77) & $\begin{array}{c}85.61 \\
(11.63)\end{array}$ & $61.64(8.37)$ & $25.71(1.83)$ & 69.75 (3.12) & $44.7(2 .)^{* * *}$ \\
\hline $\mathrm{Mg}^{+}$ & $16.03(1.27)$ & $20.77(1.57)$ & 15.08 & $12.50(0.40)$ & $22.24(0.65)$ & $14.25(0.42)^{*}$ \\
\hline $\mathrm{P} 4^{-3}$ & $7.14(0.89)$ & $7.77(1.01)$ & 5.64 (0.74) & $9.23(0.59)$ & $20.71(2.35)$ & 13.28 \\
\hline No3- & $24.39(6.33)$ & $62.77(4.36)$ & 45.57 (3.17) & $3.45(0.85)$ & $3.24(0.79)$ & $2.08(0.51)$ \\
\hline $\mathrm{Cl}^{-}$ & 7.19 (0.63) & 7.51 (1.23) & $5.45(0.89)$ & $13.21(0.71)$ & 15.69 (1.01) & $10.06(0.65)$ \\
\hline Total & 357.81 & 533.14 & 386.11 & 315.39 & 620.13 & $397.21^{*}$ \\
\hline
\end{tabular}

The concentration of ureides in the press-sap was measured only in common bean, because among the tested species only common bean transports newly fixed $\mathrm{N}_{2}$ products as ureides. Drought stress increased the level of ureides in common bean by about four-fold (Table $2 b$ ) and the accumulation increased further with prolonged drought (data not shown). However, the contribution of ureides to the osmolarity was less than $1 \%$.

The level of QAC in the press-sap was small and the accumulation in stressed plants represented merely a concentration effect. The contribution of
QAC to the osmotic potential of well-watered plants was less than 3\% across species (Table 2), and did not contribute to the osmotic adjustment in chickpea.

\section{Cations}

Potassium was the major solute in the press-sap of all species, which contributed to about $32 \%$ of the osmolarity of the tested species under wellwatered conditions, except in pea where it constituted only about $20 \%$ (Table 2). The most considerable drought-induced $\mathrm{K}^{+}$accumulation was found in the drought- sensitive species, faba 
bean. After potassium, calcium was the most abundant cation (Table 2). Under well-watered conditions, the contribution of $\mathrm{Ca}^{2+}$ to osmolarity varied from $5 \%$ in pea to $12 \%$ in common bean. The total concentration and the level of contribution to osmotic potential increased with drought, in all tested species. Drought-induced $\mathrm{Ca}^{2+}$ accumulation was not due to concentration effect but it was an effective osmoticum (Table 2). Calcium accounted for about $19 \%$ of the osmotic

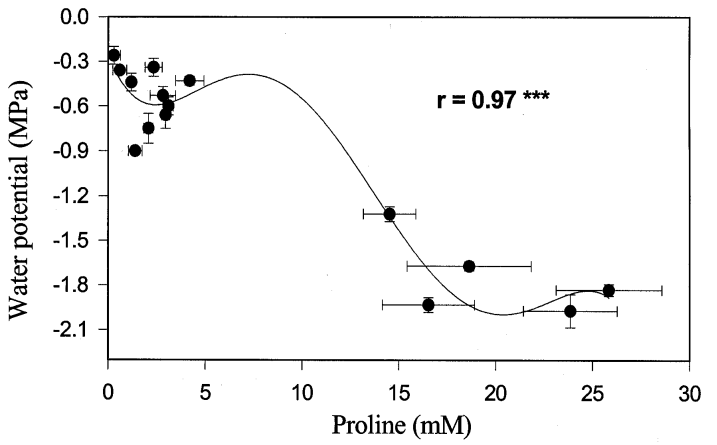

adjustment in chickpea.

Fig. 3. The relationship between proline accumulation $(\mathrm{mM})$ and water potential (MPa) in four grain legume species under 15 days drought. Bars indicate \pm SE. $\mathrm{n}=4 .{ }^{* * *}$ significant at $\mathrm{p}<0.001$.

The contribution of magnesium to the osmolarity was less than $5 \%$ across tested legumes regardless of water regimes (Table 2). Magnesium accumulation under drought was due to a concentration effect, except for chickpea, where the contribution of $\mathrm{Mg}^{2+}$ to osmotic adjustment of chickpea was only about $2 \%$.

\section{Anions}

The concentration of inorganic anions in the press-sap of grain legumes was lower relative to inorganic cations, regardless of water regimes. Drought increased phosphate concentration significantly in faba bean and chickpea plants, but scarcely contributed to the osmotic pool (Table 2). The concentration of chloride was similar to $\mathrm{PO}_{4}{ }^{3-}$, and increased with drought with the exception of common bean. The contribution of chloride to the osmolarity of the press-sap varied from $1 \%$ in pea to $4.5 \%$ in faba bean. However, the level of effective concentration of $\mathrm{PO}_{4}^{3-}$ and $\mathrm{Cl}^{-}$decreased significantly with water stress in all legumes.

Contribution of $\mathrm{NO}_{3}{ }^{-}$to the osmolarity of common bean was relatively high, about 6 and $11 \%$ of the total solutes under well-watered and stressed conditions, respectively. Nitrate concentration was relatively low in the other species (Table 2).

\section{DISCUSSION}

\section{Drought and osmotic adjustment}

Chickpea and common bean maintained turgor while faba bean and pea lost turgor when subjected to drought stress. The mechanism of turgor maintenance in these two grain legumes was apparently different. Chickpea responded to low soil water potential by reducing the tissue water potential significantly, while in common bean there was neither a change in water potential (Fig. 2) nor in relative water content (data not shown). Reduction in plant water status was strongly accompanied by solute accumulation in all legumes and as a result, osmotic potential was strongly reduced in all species (Fig. 4) except common bean. A large reduction in osmotic potential maintained a positive turgor in droughtstressed chickpea, while there was no such effect in drought-stressed plants of pea and faba bean. There was also no osmotic adjustment and no difference in osmotic pool among faba bean lines grown under drought conditions (Tilahun Amede et al., 1999).

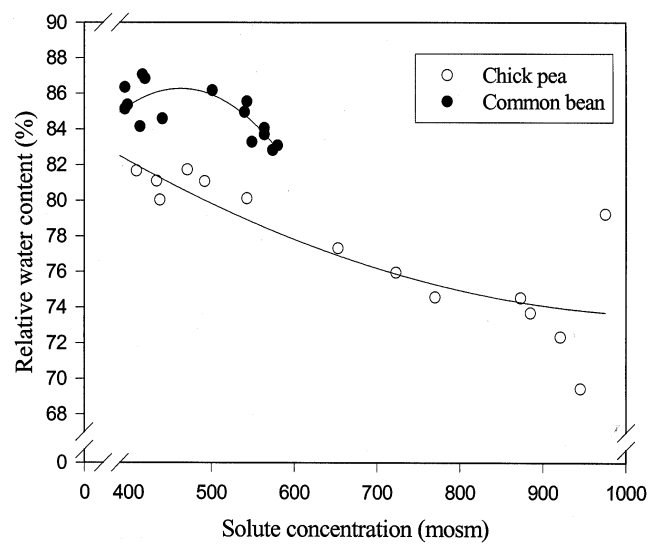

Fig. 4. The relationship between solute concentration (mosm) and relative water content $(\%)$ in grain legumes under drought.

Drought-induced solute accumulation in faba bean, common bean and pea was due to water loss and growth inhibition (Table 1). Stressed plants of faba bean lost turgor despite higher net decrease in osmotic potential $(0.67 \mathrm{MPa})$, whereas common bean maintained turgor (Fig. 2) with the smallest net osmotic decrease $(0.28 \mathrm{MPa})$. This demonstrates that a decrease in osmotic potential was not the only strategy for turgor maintenance in legumes. Turgor maintenance in common bean plants under low soil water potentials was not due to osmotic adjustment rather due to high tissue water potential (Fig. 2) possibly through stomatal 
regulation. Similarly, turgor maintenance under drought without osmotic adjustment has also been observed in cowpea plants (McCree and Richardson, 1987).

Osmotic adjustment could be also a disadvantage under very dry environments with little soil water reserve, mainly because it induces continual water loss thereby early plant death, probably by maintaining green leaf area or delaying leaf rolling. In our experiments, the degree of solute accumulation was positively associated with water use, as high solute accumulation led to higher water demand (30\% more in chickpea) than low solute accumulation (common bean). Similarly, species such as soybean, which showed higher osmotic adjustment were killed by drought before other species that lack these attributes, e.g., cow pea, under extremely dry conditions (Sinclair and Ludlow, 1986).

The dry matter yield of drought-stressed species which maintained turgor (chickpea and common bean ) was by about $20 \%$ higher (Fig. 1) than that of species which did not maintain turgor (faba bean and pea). In agreement with these results, turgor maintenance accounted for the yield performance classification of wheat genotypes under water limitations (Morgan, 1983; 1992).

\section{Species of osmotica and their contribution to osmotic adjustment}

Drought decreased or increased the sugar content of the legumes depending on species and water status of the tissue under drought conditions. Both the concentration of simple sugars and their contribution to osmotic potential in faba bean and common bean decreased with drought (Tables $2 a$ and $2 b$ ). This drought-induced shortage of assimilates was possibly engendered either by failure of leaves to capture light energy due to leaf rolling, or by stomatal closure preventing gas exchange. In contrast to common bean, which maintained higher leaf water potential (Fig. 2) and higher leaf water content under drought, faba bean had a reduced leaf water potential without substantial accumulation of osmotica, and hence turgor was lost (Fig. 2). The absence of osmotic adjustment in faba bean could not be explained in terms of assimilate shortage alone, although the concentration of sugars decreased significantly with drought. The possible reason for the decrease of sugars in faba bean could be the conversion of sugars to sorbitol. Sorbitol concentration in the press-sap of faba bean leaves was significantly higher by at least a factor of seven than for the other legumes regardless of water regime (Table 2).
In contrast, water-soluble sugars accumulated in chickpea plants to levels significantly higher (2.4 times) in drought-stressed than in control plants, and sugar concentration increased even after 15 days of water stress (data not shown). The sugar pool accounted for about $25 \%$ of total osmotic adjustment in this species, and $55 \%$ of total sugars were contributed by sucrose. Munns and Weir (1981) have reported a 70-90\% contribution of sugars to the osmotic adjustment in droughtstressed wheat plants. Inositols, (mainly pinitol) were found to be the major osmotica in legumes under drought stress conditions (Ford, 1984). In agreement with this result, there was a highly significant accumulation of inositols in chickpea plants, which accounted for about $25 \%$ of the osmotic pool under drought stress conditions. In contrast to the reports of Keller and Ludlow (1993), where a decrease in sugar concentration with increasing sugar alcohol content was found, inositol accumulated without affecting the sugar level in stressed chickpea plants. In this case, stomata may have remained open even in wilting leaves exposed to water stress, allowing further assimilation and supply of reserves (Schulze, 1986).

Drought affected nitrogen metabolism of the legume species differently. Amino acid accumulation in grain legumes could be due to either reduced demand after inhibition of growth (Schubert et al., 1995) or after impairment of protein synthesis. Amino acids accounted for 18\% of the osmotic pool in chickpea, which is in agreement with the findings of Morgan (1992) in wheat. In comparison to the other legumes, there was significantly lower concentration of sucrose but significantly higher level of nitrate in common bean plants (Table 2). This may indicate that nitrate replaces sucrose as an osmoticum as has been reported earlier in lettuce (Blom-Zandstra and Lampe, 1985).

Potassium is the major solute required for both stabilising cytoplasmic $\mathrm{pH}$ and decreasing the osmotic potential in vacuoles. In this study, $\mathrm{K}^{+}$was the principal solute species and its contribution to the osmolarity of the press-sap ranged from 19\% in pea to $33 \%$ in faba bean plants (Table 2a). Drought increased the contribution of $\mathrm{K}^{+}$from $33 \%$ to $48 \%$ in faba bean but decreased its contribution in chickpea and pea. There was an accumulation of $\mathrm{K}^{+}, \mathrm{Mg}^{2+}$ and $\mathrm{Cl}^{-}$in stressed legumes. However, at all levels, the accumulation did not exceed the concentration effect (Table 2). Ford and Wilson (1981) reported that after re-watering, the levels of $\mathrm{K}^{+}$and $\mathrm{Cl}^{-}$dropped towards the control levels in water-stressed buffalo grass and spear grass, and 
hence were not active osmotically, which agrees with our results. The contribution of $\mathrm{Ca}^{2+}$ to osmotic adjustment in chickpea was considerable, which supports earlier results of Ford (1984). Possibly, this increased $\mathrm{Ca}^{2+}$ is balancing negative charges of accumulated organic compounds.

The concentration of various solutes in legumes did not indicate the level of osmotic adjustment per se. For example, $\mathrm{K}^{+}$was the most abundant ion in the press-sap but did not contribute to osmotic adjustment, while sugars, which were not the major contributors to the osmotic potential in control plants, were the principal osmotica. This may support earlier suggestions that the major effective osmotica under drought are of organic origin (Ford, 1984; Munns, 1988). The only exception to this conclusion was calcium, which could have important roles in both electroneutrality and osmotic pressure maintenance.

Our findings confirm that there are different mechanisms of drought resistance in grain legumes. Chickpea endured drought periods with lower tissue water potential and lower water use efficiency but with higher osmotic adjustment and relatively higher biomass yield i.e. drought resistance. On the other hand, common bean plants endured drought periods with higher plant water status but lower osmotic adjustment (Fig. 2), i.e., dehydration avoidance. In general, solute accumulation per se did not guarantee osmotic adjustment. It was concluded that it is vital to differentiate solutes accumulated as a concentration effect from active osmotica using cell water volume of control plants before considering solute concentration as selection criteria for breeding drought resistant varieties/crops.

\section{ACKNOWLEDGEMENTS}

The first author would like to thank the German Academic Exchange Service (DAAD) for a scholarship grant, and Drs Reiner Fortmeier, Helge Fortmeier, Robert Feurle and Yan Feng for their technical support during the course of the study. The research work was conducted in the Institute of Plant Nutrition, University of Hohenheim, Germany.

\section{REFERENCES}

1. Bates, L.S. (1973). Rapid determination of free proline for water stress studies. Plant and Soil 39:205207.

2. Blom-zandsrta, M. and Lampe, J.E.M. (1985). The role of nitrate in the osmoregulation of lettuce
(Lactuca sativa L.) grown at different light intensities. J. Exp. Bot. 36(168):1043-1052.

3. Bose, P.C., Singh, R.K. and Ray, G.K. (1\%3). Estimation of Inositol in pharmaceutical preparations. The Indian Journal of Pharmacy 25 (12):419-420.

4. Feuerle, R. (1996). Die Sinkkapazitat a1s limitierende Große der Insulinspeicherung in Knollen von Topinambur (Helianthus tuberosus L.). Dissertation, Universitat Hohenheim.

5. Ford, C. (1984). Accumulation of low molecular weight solutes in water stressed tropical legumes. Phytochemistry 23:1007-1015.

6. Ford, C.W. and Wilson, J.R. (1981). Changes in leaves of solutes during osmotic adjustment to water stress in leaves of four tropical pasture species. Aust. J. Plant Physiol. 8:77-91.

7. Grieve, C.M. and Grattan, S.R. (1983). Rapid assay for determination of water soluble quaternary ammonium compounds. Plant and Soil 70:303307.

8. Keller, F. and Ludlow, M.M. (1993). Carbohydrate metabolism in drought-stressed leaves of pigeon-pea (Cajanus cajan). J. Exp. Bot. 44:13511359.

9. Kramer, P.J. and Boyer, J.S. (1995). Water Relations of Plants and Soils. Academic Press, 480 pp.

10. McCree, K.J. and Richardson, S.G. (1987). Stomatal closure vs osmotic adjustment A comparison of stress responses. Crop sdence 2:539-543.

11. Morgan, J.M. (1983): Osmoregulation as a selection criterion for drought tolerance in wheat. Aus. J. Agric. Res. 34: 607-614.

12. Morgan, J.M. (1992). Osmotic components and properties associated with genotypic differences in osmoregulation in wheat. AustJ. Plant Physiol. 19:67-76.

13. Munns, R. (1988). Why measure osmotic adjustment? Aust J. Plant Physiol. 15:717-726.

14. Munns, R. and Weir, R. (1981). Contribution of sugars to osmotic adjustment in elongating and expanded zones of wheat leaves during moderate water deficit at two light intervals. Aust. J. Plant Physiol.8:93-105.

15. Peoples, M.P., Faizah, A.W., Rerkasem, B. and Herridge, D.F. (1989). Methods for evaluating nitrogen fixation by nodulated legumes in the field. AGAR Monograph.

16. Premachandra, G.S., Hahn, D.T., Rhodes, D. and Joly, R.J. (1995). Leaf water relations and solute accumulation in two sorghum line exhibiting contrasting drought tolerance. J. Exp. Botany 46(293):1833-1841.

17. Rosen, H. (1957). A modified ninhydrin colorometric analysis for amino acids. Archives of Biochemistry and Biophysics 67:10-15.

18. Scholander, P.F., Hammel, H.T., Bradstreet, E.D. and Hemmingsen, E.A. (1965). Sap pressure in vascular plants. Negative hydrostatic pressure can be measured in plants. Science 148:339-346.

19. Schubert S., Serraj, R., Plies-Balzer, E. and Mengel, K. (1995). Effect of drought stress on growth, sugar concentrations and amino acid accumulation in N fixing alfalfa (Medicago sativa). J. Plant Physiol. 146:541-546. 
20. Schulze, E.D. (1986). Whole-plant responses to drought Aust.J. Plant Physiol. 13:127-41.

21. Sinclair, T.R. and Ludlow, M.M. (1986). Influence of soil water supply on the plant water balance of four tropical grain legumes. Aust. J. Plant Physiol. 13:329-341.

22. Singh, T .N., Paleg, L.G. and Aspinall, D. (1973): Stress metabolism I. Nitrogen metabolism and growth in the barley plant during water stress. Aust. J. Bio. Sci. 26:45-56.

23. Sundaresan S. and Sudhakaran, P.R. (1995). Water stress-induced alterations in the proline metabo- lism of drought-susceptible and tolerant cassava (Manihot esculenta) cultivars. Physiol. Plant 94:635-642.

24. Tilahun Amede (1998). Analysis of Drought Resistance in grain legumes: The case of Vicia faba L., Pisum sativum L., Phaseolus vulgaris L., and Cicer arietin $\mathrm{L} . \mathrm{PhD}$ thesis, University of Hohenheim, Ulrich Grauer Publishing, Stuttgart, Germany 135 pp.

25. Tilahun Amede, Kittlitz, E.V. and Schubert, S. (1999). Differential drought responses of Faba bean (Vicia faba L.) Inbred lines. J. Agronomy and Crop Science 183:35-45.

26. Timpa, D.J., Burke, J.J., Quisenberry, J.E. and Wendt, .E. (1986): Effects of water stress on the organic acid and carbohydrate composition of cotton. Plant. Ph siol. 82:724-728.

27. Vereecken, H., Maes, J., Feyen, J. and Darius, P. (1989). Estimating the soil moisture retention characteris- tic from texture, bulk density, and carbon content. Soil Science 148(6):389-403. 